ISSN 0103-8478

\title{
Volatile profile of yellow passion fruit juice by static headspace and solid phase microextraction techniques
}

\author{
Perfil volátil do suco do maracujá-amarelo por técnicas de extração em headspace estático e \\ microextração em fase sólida
}

\author{
Gilberto Costa Braga ${ }^{I}$ Adna Prado II Jair Sebastião da Silva Pinto ${ }^{\text {II }}$ \\ Severino Matias de Alencar ${ }^{I I}$
}

\begin{abstract}
The profile of volatile compounds of yellow passion fruit juice was analyzed by solid phase microextraction headspace (HS-SPME) and optimized static headspace (S-HS) extraction techniques. Time, temperature, $\mathrm{NaCl}$ concentration and sample volume headspace equilibrium parameters was adjusted to the S-HS technique. The gaseous phase in the headspace of samples was collected and injected into a gas chromatograph coupled to a mass spectrometer. In the HS-SPME technique was identified 44 volatile compounds from the yellow passion fruit juice, but with S-HS only 30 compounds were identified. Volatile esters were majority in both techniques, being identified ethyl butanoate, ethyl hexanoate, (3z)-3-hexenyl acetate, hexyl acetate, hexyl butanoate and hexyl hexanoate. Aldehydes and ketones were not identified in $\mathrm{S}$-HS, but were in HS-SPME. $\beta$-Pinene, p-cymene, limonene, (Z)- $\beta$-ocimene, (E)- $\beta$-ocimene, $\gamma$-terpinene, $\alpha$-terpinolene and (E) -4,8-dimethyl-1, 3,7 - nonatriene terpenes were identified in both techniques. This study showed that the S-HS optimized extraction technique was effective to recovery high concentrations of the major volatile characteristics compounds in the passion fruit, such as ethyl butanoate and ethyl hexanoate, which can be advantageous due to the simplicity of the method.
\end{abstract}

Key words: Passiflora edulis $f$. flavicarpa Deg., GC/MS, SPME, $H S$, aroma profile.

\section{RESUMO}

O perfil de compostos voláteis do suco de maracujáamarelo foi analisado pelas técnicas de extração microextração em fase sólida (SPME-HS) e headspace estático (S-HS). Os parâmetros de equilibrio do headspace tempo, temperatura, concentração de $\mathrm{NaCl}$ e volume da amostra foram ajustados para a técnica $S$-HS. Em ambas as técnicas de extração, a fase gasosa no headspace das amostras foi recolhida e injetada em cromatógrafo gasoso acoplado a espectrômetro de massas. $\mathrm{Na}$ técnica SPME-HS, foram identificados 44 compostosvoláteis no suco do maracujá-amarelo e, em S-HS, foram identificados 30 compostos. Ésteres voláteis foram majoritários em ambas as técnicas, sendo identificados butanoato de etila, hexanoato de etila, (3z)-3-hexenil acetato, hexil acetato, hexil butanoatoe hexil hexanoato. Aldeidos e cetonas não foram identificados com a técnica S-HS. Os terpenos $\beta$-pineno, p-cimeno, limoneno, (Z)- $\beta$-ocimeno, (E)- $\beta$-ocimeno, $\gamma$-terpineno, $\alpha$-terpinoleno $e(E)$ 4,8-dimetil-1,3,7-nonatrieno foram identificados em ambas as tıcnicas.. Este estudo mostrou que a técnica de extração otimizada S-HS foi eficaz para a recuperação de altas concentrações dos principais compostos voláteis característicos do maracujá, como o butanoato de etila e o hexanoate deetila, o que é vantajoso, devido à simplicidade do método.

Palavras-chave: Passiflora edulis f. flavicarpa Deg., CG/EM, SPME, HS, perfil de aromas.

\section{INTRODUCTION}

The yellow passion fruit (Passiflora edulis f. flavicarpa Deg.) is the most widely cultivated Passiflora species in Brazil and much appreciated by the intense aroma and taste of its juice. The chemical composition of yellow passion fruit juice is characterized by the presence of volatile and non-volatile substances, which define their sensory and nutritional attributes. In the case of volatile compounds, they interfere directly with the sensory quality of the fruit and its processed products (PONTES et al., 2009). The juice of yellow passion fruit has an "ester" floral aroma with exotic tropical

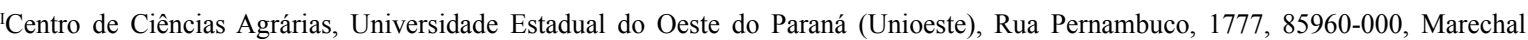
Cândido Rondon, PR, Brasil. E-mail: gcb1506@gmail.com. Corresponding author.

"Laboratório de Bioquímica e Análise Instrumental, Departamento de Agroindústria, Alimentos e Nutrição (LAN), Escola Superior de Agricultura "Luiz de Queiroz" (ESALQ), Universidade de São Paulo (USP), Piracicaba, SP, Brasil. Recebido 03.06.13 Aprovado 21.04.14 Devolvido pelo autor 13.10.14 CR-2013-0777.R2
} 
characteristic of sulfurous note (CARASEK \& PAWLISZYN, 2006). Notably, volatiles aroma of fruits are composed of a complex group of chemical substances, such as aldehydes, alcohols, ketones, esters, lactones and terpenes (JORDÁN et al., 2002). However, terpenes and esters are more related to the aroma of passion fruit juice (MACORIS et al., 2011). Additionally, the major volatile compounds identified in yellow passion fruit juice belong to the methyl and ethyl esters (WERKHOFF et al., 1998; CARASEK \& PAWLISZYN, 2006). The levels of individual volatile compounds related to the aroma profile in food matrix are largely influenced by the extraction technique of the volatile fraction used in gas chromatograph analysis (BICCHI et al., 2008). Headspace sampling techniques are widely used for providing volatile profiles near the profiles experienced by humans. Based on the collection of the volatile compounds in the gaseous phase above, a sample under defined conditions is dependent on the volatility of the aromatic compounds (GUTH \& GROSCH, 1993). Among the headspace techniques currently used for the extraction of aromatic volatiles, solid-phase microextraction (HS-SPME) has been applied for isolation of volatile compounds from fruits (BARBONI et al., 2009; PONTES et al., 2009; FIGOLI et al., 2010, ALVAREZet al., 2012). This technique is based on a dynamic process of adsorption of volatiles on the vapor phase in the sample headspace in a silica fiber coated with an adsorbent polymer and has high sensitivity in the volatiles extraction with a wide range of polarity (BICCHI et al. 2008). In the static headspace sampling techniques (S-HS), the equilibrium between the sample and the headspace gas phase must be reached, and a gaseous fraction of the headspace is collected directly for analysis by gas chromatograph (SNOW \& SLACK, 2002; WANG et al., 2008). The S-HS technique is simpler and faster and has been used in comparative analysis of the flavor profile of vegetable matrices (MILLER \& STUART, 1999; VARMING et al., 2004; BYLAITE \&MEYER, 2006; UBEDA et al. 2011). However, S-HS has not yet been used in the analysis of yellow passion fruit juice volatiles. The S-HS procedure is free of solvents, demands little sample handling, and can be automated, but its sensitivity is considered low compared to SPME, being indicated for the analysis of compounds whose boiling points are low (MESTRES et al., 2002). Nevertheless, the S-HS sensitivity can be increased by salt addition, $\mathrm{pH}$ control or increasing the equilibrium temperature during sample heating (B'HYMER, 2003), which can improve the recovery of major volatile compounds of the aroma of passion fruit, such as esters and terpenes. Therefore, the aim of this study was to determine the profile of volatile compounds of the yellow passion fruit juice through the headspace solid-phase microextraction (HS-SPME) and optimized static headspace (S-HS) extraction techniques.

\section{MATERIALS AND METHODS}

Yellow passion fruits were harvested in April 2011 in an orchard in Piracicaba, São Paulo State, Brazil, located at $22^{\circ} 43^{\prime} 31^{\prime \prime}$ south latitude and $47^{\circ} 38^{\prime} 57^{\prime \prime}$ west longitude. Fruits were selected on the yellow-ripe physiological stage, healthy and without physical defects. For assays, 15 fruits were chosen with lengths between 8 and $10 \mathrm{~cm}$. A cross section was made in each fruit to extract the pulp (juice and seed). The juice was separated from the seed by drainage through a plastic sieve and then was frozen and stored at $-24^{\circ} \mathrm{C}$ until the time of analysis. The frozen juice samples were first thawed in water bath at $25^{\circ} \mathrm{C}$ for analyses on HS-SPME and S-HS. The extractions were performed without $\mathrm{pH}$ adjustment. All analyzes were performed in triplicate. For the extraction in HS-SPME, the equilibrium parameters were established according to PONTES et al. (2009) with modifications. In a $20 \mathrm{~mL}$ flask $0.2 \mathrm{~mL}$ aliquot of juice sample was diluted with $1.0 \mathrm{~mL}$ Milli-Q water (Millipore Corporation, Brazil). The solution ionic strength was increased to improve the extraction efficiency with the addition of $17 \% \mathrm{NaCl}(0.2 \mathrm{~g}$, $\left.\mathrm{Wv}^{-1}\right)$ in the diluted sample. The vial was tightly sealed with a screw cap with coupled silicone septum. The fiber used in the HS-SPME extraction had the coating of polydimethylsiloxane/divinylbenzene (PDMS / DVB, Supelco Inc., Bellefonte, PA, USA). The fiber was exposed in the sample headspace and maintained for 20 minutes at $50^{\circ} \mathrm{C}$, with the sample in a thermostatic magnetic stirrer at 450rpm. After the extraction procedure by adsorption in the headspace, the fiber was inserted into the injector of the gas chromatograph-mass spectrometry system for 6 minutes in the splitless mode, where the extracted volatiles were thermally desorbed at $250^{\circ} \mathrm{C}$.

In the S-HS technique the parameters of equilibrium between gas and liquid phases of the passion fruit sample were adjusted to improve the extraction efficiency with higher recovery levels and volatile concentration as possible. The time and temperature, sample volume and the $\mathrm{NaCl}$ concentration were considered as equilibrium parameters in the gas phase of the sample. The $\mathrm{NaCl}$ concentration was adjusted by adding 10, 20 and 
$30 \%\left(\mathrm{wV}^{-1}\right)$ salt and the control without salt. The $\mathrm{NaCl}$ addition in the sample decreases the solubility of volatile compounds, increasing its volatility in the sample (PONTES et al., 2009). The optimal salt concentration was established keeping invariable the conditions of time and equilibrium temperature in 20 minutes and $70^{\circ} \mathrm{C}$. Times of 10,20 and 30 minutes and temperatures of $50,60,70,80$ and $90^{\circ} \mathrm{C}$ were tested. Above $90^{\circ} \mathrm{C}$ the sample reached the boiling point and therefore was chosen as the limit temperature. The choice of best time of equilibrium was carried out at the temperature of $60^{\circ} \mathrm{C}$. The selection of the binomial time and temperature of equilibrium was achieved with the addition of the best $\mathrm{NaCl}$ concentration adjusted $\left(\mathrm{w} \mathrm{v}^{-1}\right)$ in the juice sample. The adjusted condition of equilibrium in the headspace for temperature and time was used for adjusting the sample volume with $2.5,5.0$ and $7.5 \mathrm{~mL}$. The heating of the juice sample at all procedures for balance adjustment in the headspace occurred under constant stirring in a glass flask silalized $(20 \mathrm{~mL})$ and hermetically sealed with a screw cap with a coupled silicone septum. The volume of $1.5 \mathrm{~mL}$ was collected from the headspace and injected into the gas chromatograph with Shimadzu automatic injector equipped with heating oven of the sample.

The volatile compounds sampled in S-HS and HS-SPME were analyzed in a gas chromatograph Shimadzu 2010 coupled to a mass spectral detector Shimadzu QP 2010 Plus. The samples were separated in DB5 capillary column $(30 \mathrm{mx} 0.25 \mathrm{~mm} \times 0.25 \mu \mathrm{m}$, J\&W Scientific, Palo Alto, CA). Mass spectra and total ion currents (TIC chromatograms) were obtained by automatic scanning with energy ionization $70 \mathrm{eV}$, in the mass range $\mathrm{m} / \mathrm{z} 35-500$. The temperature ramp began at $40^{\circ} \mathrm{C}$ maintained for $4.0 \mathrm{~min}$, then $150^{\circ} \mathrm{C}$ at $3.0^{\circ} \mathrm{C} \mathrm{min}{ }^{-1}$ and $250^{\circ} \mathrm{C}$ at $15^{\circ} \mathrm{C} \mathrm{min}^{-1}$ maintained for 2.0 min. Helium was used as carrier gas at linear velocity of $36.1 \mathrm{~cm} \mathrm{~s}^{-1}$. Kovats indices of linear retention (KI) of the chromatographic peaks obtained were determined experimentally based on the retention time of a homologous n-alkanes series (C6-C18).

Peaks were tentatively identified based on: I) comparison of fragmentation patterns using the mass spectral database of the library Wiley8 of the GCMSsolution Software identification system (Mass Spectrometer Systems - Shimadzu) II) by comparing the Kovats retention indices (KI) obtained experimentally with theoretical ratios obtained from the literature. The compounds were expressed as relative amounts to the peak areas percentage.

The Analysis of variance was used to check for significant differences in tests of headspace balance adjustment and among the methods of volatiles extraction. The significance level $\mathrm{P}<0.05$ was considered. The statistical package SAEG (UFV - Viçosa, MG, Brazil) was used.

\section{RESULTS AND DISCUSSION}

HS-SPME and S-HS are are simple, rapid, solvent-free extraction techniques and can help to analyze the volatile profile of vegetable matrices that have intense aroma to human scent, as the case of the yellow passion fruit juice. The temperature is a key parameter in the extraction yield and, with time, have a significant effect on the balance of the gas phase in the sample headspace, since they determine the vapor pressure of volatiles (CARASEK \& PAWLISZYN, 2006), and for this reason, adjustments were made. In addition, the $\mathrm{NaCl}$ concentration and volume of juice samples were also adjusted. The results of these assays are shown in figure 1. There were significant increases $(\mathrm{P}<0.05)$ in total area of peaks with increasing equilibrium time in the range of 10 to $30 \mathrm{~min}$ (Figure 1a), but between 20 and $30 \mathrm{~min}$ there were no significant differences among peak areas. Thus, the time of 20 min was selected because it was the shortest not significant contrast time. While adjusting the equilibrium temperature, the extraction time of $20 \mathrm{~min}$ was maintained constant at all temperatures tested. According to figure 1b, increases in peak area values show that the extraction efficiency increased significantly $(\mathrm{P}<0.01)$ with increasing equilibrium temperature and the maximum extraction efficiency was achieved at $90^{\circ} \mathrm{C}$. Preliminary analysis of the chromatographic peaks for the sample at 50 , 60 and $90^{\circ} \mathrm{C}$ (not reported) showed no degradation of the volatiles in the sampling conditions at $90^{\circ} \mathrm{C}$ for 20 minutes.

No significant differences were found for the results of the total area when different $\mathrm{NaCl}$ concentrations were tested in the yellow passion fruit juice (Figure 1c), showing that the use of salt $(\mathrm{NaCl})$ is not recommended in whole juice samples of yellow passion fruit by adding no increase efficiency in the extraction of volatiles in the S-HS technique. The $\mathrm{NaCl}$ addition in the sample aims to improve the extraction efficiency by increasing the ionic strength and decrease the solubility of volatile compounds soluble in the aqueous phase (PONTES et al., 2009). Probably, there was no effect of salt addition, since the ionic strength in the juice sample should be sufficiently high, justifying the high volatility of the volatile compounds of the yellow passion fruit. According to figure $1 \mathrm{~d}$, increasing the volume of 

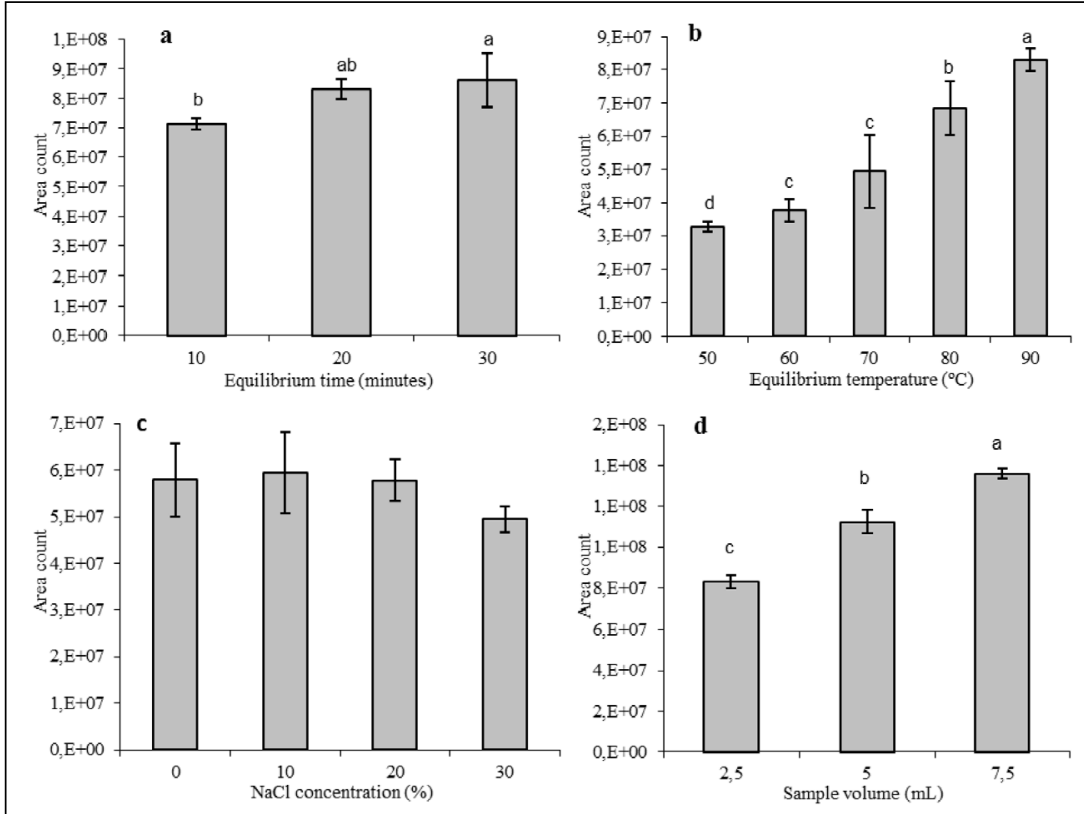

Figure 1 -Total GC peak areas of yellow passion fruit juice (P. edulis f. Flavicarpa Deg.) volatiles extracted by static headspace (S-HS) for the parameters time (a), temperature (b), $\mathrm{NaCl}$ concentration (c, treatments non-statistically significant) and sample volume (d) at the headspace equilibrium. Vertical bars mean standard deviation $(\mathrm{n}=3)$. Same letters do not differ at $\mathrm{P}<0.05$.

juice influenced in significant increases $(\mathrm{P}<0.01)$ in the total area values of volatiles peaks, showing that the most efficient extraction of volatiles was achieved in $7.5 \mathrm{~mL}$ juice sample and therefore, it was the chosen volume. Thus, the adjusted conditions of headspace equilibrium in the volatiles extraction in the S-HS technique were $90^{\circ} \mathrm{C}$ for $20 \mathrm{~min}, 7.5 \mathrm{~mL}$ sample volume for the juice without $\mathrm{NaCl}$ addition.

The results of yellow passion fruit volatile profiles obtained through S-HS and HS-SPME extraction techniques are shown in table 1. Kovats retention linear indices (KI) were calculated for each peak and, when evaluable, they were compared with the reference literatures in order to ensure the compounds identification. The percentage of total area for the S-HS and HSSPME extraction techniques were $96.85 \pm 1.59 \%$ and $93.58 \pm 1.25 \%$, respectively. The differences in the total percentages $(100 \%)$ represent the peak areas of the volatiles that have not had their identity confirmed by comparisons of mass spectra and Kovats linear retention indices (KI).

Among the different types offibers routinely used for sampling of volatiles, which have a range of polarities and different mechanisms of selectivity, the PDMS/DVB fiber (polydimethylsiloxane/ divinylbenzene) was used in this study and the conditions of headspace equilibrium in the extraction with the fiber had been pre-established. The equilibrium conditions were extraction temperature of $50^{\circ} \mathrm{C}$, extraction time of $20 \mathrm{~min}$, stirring at $450 \mathrm{rpm}$ and the addition of $17 \% \mathrm{NaCl}\left(\mathrm{w} \mathrm{v}^{-1}\right)$. In a comparative study between five types of fibers it was observed that PDMS/DVB fiber was the most efficient for volatiles extraction in a sample of purple passion fruit juice (PONTES et al., 2009). These authors also found a high affinity of this fiber for ethyl esters, alcohols and terpenes.

According to table 1, analysis of the volatile profile of passion fruit juice (P. edulis f. Flavicarpa Deg.) in GC/MS by the S-HS and HSSPME techniques resulted in 30 and 44 identified volatile compounds, respectively. Esters, terpenes, alcohols, aldehydes and ketones formed the groups of volatiles identified in the study of yellow passion fruit and they probably play an important role in the juice sensory profile (WERKHOFF et al., 1998; MACORIS et al., 2011). In the HS-SPME technique recovery of volatiles was more efficient with the identification of 24 esters, 8 terpenes, 6 alcohols, 3 aldehydes, 
Table 1 -Volatile profile of yellow passion fruit juice (P. edulis f. Flavicarpa Deg.) tentatively identified by GC/MS (DB5 column) and extracted by the static-headspace (S-HS) (30 compounds) and headspace solid-phase microextraction (HS-SPME)(44 compounds).

\begin{tabular}{|c|c|c|c|c|c|c|}
\hline & \multicolumn{2}{|c|}{------------KI-DB5---------. } & \multirow{2}{*}{ Volatile compound } & \multicolumn{2}{|c|}{----------- Relative area \%--------- } & \multirow{2}{*}{ Identification $^{\mathrm{a}}$} \\
\hline & S-HS & HS-SPME & & S-HS & HS-SPME & \\
\hline & & & Ester & & & \\
\hline 1 & 602 & 603 & Ethyl acetate & $0.16 \pm 0.05$ & $0.03 \pm 0.01$ & $\mathrm{MS}, \mathrm{KI}^{\mathrm{b}}, \mathrm{KI}^{\mathrm{c}}$ \\
\hline 2 & 778 & 782 & Ethyl butanoate & $16.86 \pm 0.32$ & $3.42 \pm 0.63$ & $\mathrm{MS}, \mathrm{KI}^{\mathrm{b}}, \mathrm{KI}^{\mathrm{c}}$ \\
\hline 3 & 790 & - & Butyl acetate & $0.31 \pm 0.03$ & - & $\mathrm{MS}, \mathrm{KI}^{\mathrm{d}}$ \\
\hline 4 & 981 & 982 & Butyl butanoate & $0.15 \pm 0.01$ & $0.07 \pm 0.05$ & $\mathrm{MS}, \mathrm{KI}^{\mathrm{b}}$, \\
\hline 5 & 985 & 987 & Ethyl hexanoate & $21.15 \pm 0.29$ & $11.11 \pm 1.08$ & $\mathrm{MS}, \mathrm{KI}^{\mathrm{b}}$ \\
\hline 6 & 993 & 995 & (3z)-3-Hexenyl acetate & $5.16 \pm 0.10$ & $6.23 \pm 0.12$ & $\mathrm{MS}, \mathrm{KI}^{\mathrm{b}}$ \\
\hline 7 & 997 & - & Ethyl 2-hexanoate & $0.11 \pm 0.01$ & - & $\mathrm{MS}$ \\
\hline 8 & 1001 & 1002 & Hexyl acetate & $7.96 \pm 0.06$ & $6.51 \pm 0.63$ & $\mathrm{MS}, \mathrm{KI}^{\mathrm{b}}, \mathrm{KI}^{\mathrm{d}}$ \\
\hline 9 & 1092 & 1092 & Propyl hexanoate & $0.06 \pm 0.02$ & $0.17 \pm 0.03$ & $\mathrm{MS}, \mathrm{KI}^{\mathrm{b}}, \mathrm{KI}^{\mathrm{f}}$ \\
\hline 10 & 1104 & 1104 & Hexyl propanoate & $0.07 \pm 0.01$ & $0.13 \pm 0.02$ & $\mathrm{MS}, \mathrm{KI}^{\mathrm{b}}$ \\
\hline 11 & - & 1167 & Benzyl acetate & - & $0.18 \pm 0.02$ & $\mathrm{MS}, \mathrm{KI}^{\mathrm{b}}, \mathrm{KI}^{\mathrm{f}}$ \\
\hline 12 & 1190 & 1191 & (3z)-3-Hexenyl butanoate & $1.62 \pm 0.03$ & $3.26 \pm 0.05$ & $\mathrm{MS}, \mathrm{KI}^{\mathrm{b}}, \mathrm{KI}^{\mathrm{c}}, \mathrm{KI}^{\mathrm{f}}$ \\
\hline 13 & 1193 & 1194 & Ethyl (4z)-4-octenoate & $0.64 \pm 0.03$ & $1.71 \pm 0.16$ & $\mathrm{MS}, \mathrm{KI}^{\mathrm{b}}$ \\
\hline 14 & 1196 & 1198 & Hexyl butanoate & $9.75 \pm 0.10$ & $11.88 \pm 0.14$ & $\mathrm{MS}, \mathrm{KI}^{\mathrm{b}}, \mathrm{KI}^{\mathrm{c}}, \mathrm{KI}^{\mathrm{f}}$ \\
\hline 15 & 1202 & 1202 & Ethyl octanoate & $0.64 \pm 0.02$ & $1.40 \pm 0.03$ & $\mathrm{MS}, \mathrm{KI}^{\mathrm{b}}, \mathrm{KI}^{\mathrm{f}}$ \\
\hline 16 & - & 1206 & Ethyl 3-octenoate & - & $0.09 \pm 0.01$ & $\mathrm{MS}, \mathrm{KI}^{\mathrm{b}}$ \\
\hline 17 & 1217 & 1217 & Octyl acetate & $0.08 \pm 0.00$ & $0.28 \pm 0.02$ & $\mathrm{MS}, \mathrm{KI}^{\mathrm{b}}, \mathrm{KI}^{\mathrm{g}}$ \\
\hline 18 & 1242 & 1242 & Hexyl 2-methylbutanoate & $0.07 \pm 0.00$ & $0.29 \pm 0.02$ & $\mathrm{MS}, \mathrm{KI}^{\mathrm{b}}, \mathrm{KI}^{\mathrm{c}}$ \\
\hline 19 & - & 1295 & Hexyl pentanoate & - & $0.32 \pm 0.03$ & $\mathrm{MS}, \mathrm{KI}^{\mathrm{b}}, \mathrm{KI}^{\mathrm{c}}$ \\
\hline 20 & - & 1380 & 1-Pentyl-2-propenyl butanoate & - & $0.12 \pm 0.00$ & MS \\
\hline 21 & 1384 & 1386 & (3z)-3-Hexenyl hexanoate & $1.74 \pm 0.19$ & $6.48 \pm 0.34$ & $\mathrm{MS}, \mathrm{KI}^{\mathrm{b}}, \mathrm{KI}^{\mathrm{c}}, \mathrm{KI}^{\mathrm{f}}$ \\
\hline 22 & 1389 & 1392 & Hexyl hexanoate & $9.49 \pm 0.74$ & $17.47 \pm 1.33$ & $\mathrm{MS}, \mathrm{KI}^{\mathrm{b}}, \mathrm{KI}^{\mathrm{c}}, \mathrm{KI}^{\mathrm{f}}$ \\
\hline 23 & - & 1394 & 4-Oxocyclohexyl acetate & - & $0.66 \pm 0.05$ & MS \\
\hline 24 & - & 1398 & Ethyl decanoate & - & $0.12 \pm 0.01$ & $\mathrm{MS}, \mathrm{KI}^{\mathrm{b}}, \mathrm{KI}^{\mathrm{f}}$ \\
\hline 25 & - & 1463 & Ethyl cinnamate & - & $0.26 \pm 0.04$ & $\mathrm{MS}, \mathrm{KI}^{\mathrm{b}}, \mathrm{KI}^{\mathrm{f}}$ \\
\hline \multirow[t]{3}{*}{26} & 1554 & 1554 & Hexyl octanoate & $0.07 \pm 0.01$ & $0.45 \pm 0.03$ & $\mathrm{MS}, \mathrm{KI}^{\mathrm{f}}$ \\
\hline & & & Total & $79.09 \pm 2.02$ & $72.64 \pm 4.85$ & \\
\hline & & & Terpene & & & \\
\hline 27 & 974 & 975 & $\beta$-Pinene & $4.15 \pm 0.32$ & $2.32 \pm 0.07$ & $\mathrm{MS}, \mathrm{KI}^{\mathrm{b}}, \mathrm{KI}^{\mathrm{c}}$ \\
\hline 28 & 1010 & 1011 & $\rho$-Cimene & $0.10 \pm 0.01$ & $0.06 \pm 0.01$ & $\mathrm{MS}, \mathrm{KI}^{\mathrm{b}}, \mathrm{KI}^{\mathrm{e}}$ \\
\hline 29 & 1014 & 1016 & Limonene & $2.21 \pm 0.16$ & $1.19 \pm 0.01$ & $\mathrm{MS}, \mathrm{KI}^{\mathrm{b}}, \mathrm{KI}^{\mathrm{f}}$ \\
\hline 30 & 1027 & 1028 & (Z)- $\beta$-Ocimene & $0.40 \pm 0.04$ & $0.23 \pm 0.02$ & $\mathrm{MS}, \mathrm{KI}^{\mathrm{b}}, \mathrm{KI}^{\mathrm{c}}, \mathrm{KI}^{\mathrm{e}}$ \\
\hline 31 & 1038 & 1040 & (E)- $\beta$-Ocimene & $9.48 \pm 0.39$ & $5.85 \pm 0.07$ & $\mathrm{MS}, \mathrm{KI}^{\mathrm{c}}, \mathrm{KI}^{\mathrm{f}}$ \\
\hline 32 & 1049 & 1050 & $\gamma$-Terpinene & $0.25 \pm 0.03$ & $0.21 \pm 0.01$ & $\mathrm{MS}, \mathrm{KI}^{\mathrm{b}}$ \\
\hline 33 & 1082 & 1083 & $\alpha$-Terpinolene & $1.55 \pm 0.11$ & $1.46 \pm 0.08$ & $\mathrm{MS}, \mathrm{KI}^{\mathrm{b}}, \mathrm{KI}^{\mathrm{c}}$ \\
\hline \multirow[t]{3}{*}{34} & 1114 & 1115 & (E)-4.8-Dimethyl-1.3.7-nonatriene & $1.43 \pm 0.13$ & $0.62 \pm 0.04$ & MS, \\
\hline & & & Total & $19.57 \pm 1.19$ & $11.94 \pm 0.31$ & \\
\hline & & & Alcohol & & & \\
\hline 35 & 843 & 845 & Hexanol & $0.77 \pm 0.05$ & $2.16 \pm 0.82$ & $\mathrm{MS}, \mathrm{KI}^{\mathrm{b}}, \mathrm{KI}^{\mathrm{c}}$ \\
\hline 36 & 1066 & 1066 & Octanol & $0.10 \pm 0.01$ & $1.81 \pm 0.15$ & $\mathrm{MS}, \mathrm{KI}^{\mathrm{b}}, \mathrm{KI}^{\mathrm{c}}, \mathrm{KI}^{\mathrm{f}}$ \\
\hline 37 & 1096 & 1097 & Linalool & $0.63 \pm 0.03$ & $1.89 \pm 0.18$ & $\mathrm{MS}, \mathrm{KI}^{\mathrm{b}}, \mathrm{KI}^{\mathrm{d}}, \mathrm{KI}^{\mathrm{d}}$ \\
\hline 38 & - & 1180 & 4-Terpineol & - & $0.64 \pm 0.03$ & $\mathrm{MS}, \mathrm{KI}^{\mathrm{b}}, \mathrm{KI}^{\mathrm{g}}, \mathrm{KI}^{\mathrm{f}}$ \\
\hline 39 & - & 1261 & (Z)-3.7-Dimethyl-2.6-octadien-1-ol & - & $0.31 \pm 0.04$ & $\mathrm{MS}, \mathrm{KI}^{\mathrm{b}}, \mathrm{KI}^{\mathrm{f}}$ \\
\hline \multirow[t]{3}{*}{40} & - & 1279 & Decan-1-ol & - & $0.12 \pm 0.03$ & $\mathrm{MS}, \mathrm{KI}^{\mathrm{b}}, \mathrm{KI}^{\mathrm{f}}$ \\
\hline & & & Total & $1.50 \pm 0.09$ & $6.93 \pm 1.25$ & \\
\hline & & & Aldehyde & & & \\
\hline 41 & - & 1102 & Nonanal & - & $0.32 \pm 0.06$ & $\mathrm{MS}, \mathrm{KI}^{\mathrm{b}}, \mathrm{KI}^{\mathrm{c}}, \mathrm{KI}^{\mathrm{g}}, \mathrm{KI}^{\mathrm{f}}$ \\
\hline 42 & - & 1210 & Decanal & - & $0.29 \pm 0.07$ & $\mathrm{MS}, \mathrm{KI}^{\mathrm{b}}, \mathrm{KI}^{\mathrm{g}}, \mathrm{KI}^{\mathrm{f}}$ \\
\hline 43 & - & 1226 & $\begin{array}{l}\beta \text {-Cyclocitral } \\
\text { Ketone }\end{array}$ & - & $0.08 \pm 0.01$ & $\mathrm{MS}, \mathrm{KI}^{\mathrm{b}}, \mathrm{KI}^{\mathrm{c}}$ \\
\hline 44 & - & 1451 & Geranylacetone & - & $0.23 \pm 0.04$ & $\mathrm{MS}, \mathrm{KI}^{\mathrm{b}}, \mathrm{KI}^{\mathrm{c}}, \mathrm{KI}^{\mathrm{f}}$ \\
\hline 45 & - & 1482 & $\beta$-Ionone & - & $0.10 \pm 0.01$ & $\mathrm{MS}, \mathrm{KI}^{\mathrm{b}}, \mathrm{KI}^{\mathrm{e}}, \mathrm{KI}^{\mathrm{f}}$ \\
\hline & & & Other & & & \\
\hline 46 & - & 601 & Acetic acid & - & $0.62 \pm 0.97$ & $\mathrm{MS}, \mathrm{KI}^{\mathrm{b}}, \mathrm{KI}^{\mathrm{c}}$ \\
\hline Total & 30 & 44 & & $96.85 \pm 1.59$ & $93.58 \pm 1.25$ & \\
\hline
\end{tabular}

${ }^{*}$ mean \pm standard deviation $(\mathrm{n}=3)$

${ }^{\text {a }}$ MS, Comparison of mass spectra from Wiley8 library and NISTdatabase (http://webbook.nist.gov).

${ }^{a} \mathrm{KI}$, comparisons with the linear retention indices (Kovats Index) from the literature.

KI ${ }^{\mathrm{b}}$ http://www.pherobase.com; KI'RODRÍGUEZ-BURRUEZO et al., 2010; KI DU et al., 2011; KI MAHATTANATAWEE et al., 2007;

KI http://www.flavornet.org/flavornet.html; KI ${ }^{\mathrm{g}}$ BYLAITE \&MEYER, 2006. 
2 ketones and one acid, while in S-HS extraction were identified 19 esters, 8 terpenes and 3 alcohols, not being identified in this extraction procedure the volatiles ketone and aldehyde groups. Among the esters identified in both extraction techniques, ethyl butanoate, ethyl hexanoate, (3z)-3-hexenyl acetate, hexyl acetate, hexyl butanoate and hexyl hexanoate were the major ones. However, similarities in area percentage among the esters identified in S-HS and HS-SPME were found only for (3Z)-3-hexenyl acetate $(5.16 \% \pm 0.10$ and $6.23 \pm 0.12 \%$ respectively), hexyl acetate $(7.96 \pm 0.06 \%$ and $6: 51 \pm 0.63 \%$, respectively) and hexyl butanoate $(9.75 \pm 0.10 \%$ and $11.88 \pm 0.14 \%$ respectively), while the greatest differences were found for ethyl butanoate $(16.86 \pm 0.32 \%$ and $3.42 \pm 0.63 \%$ respectively), ethyl hexanoate (21:15 $\pm 0.29 \%$ and $11.11 \pm 1.08 \%$, respectively) and hexyl hexanoate $(9.49 \pm 0.74 \%$ and $17.47 \pm 1.33 \%$, respectively).

According to reports in scientific study,volatile esters are the major compounds with the highest concentration of yellow passion fruit juice(JORDÁN et al.,2002; CARASEK \& PAWLISZYN, 2006). In addition, hexyl hexanoate, hexyl butanoate, ethyl butanoate, (Z)-3-hexenyl hexanoate, (Z)-3-hexenyl butanoate and ethyl hexanoate are the most abundant compounds found among the volatile fraction of yellow passion fruit juice (WERKHOFF et al., 1998; BRAT et al., 2000). In the present study, these compounds were identified in the two extraction techniques. Using dynamic headspace MACORIS et al. (2011) found ethyl butanoate in both organic and conventional passion fruit pulps produced in Brazil, with 52\%and $57 \%$ of the total relative area of the chromatogram, respectively. Meantime, in the present study this specific compound was found in high concentrations only when the HS technique was used. However, the esters (Z)-3-hexenyl hexanoate and (Z)-3-hexenyl butanoate showed significant higher concentrations in HS-SPME extraction with area percentages of $6.48 \pm$ $0.34 \%$ and $3.26 \pm 0.05 \%$ respectively, while in S-HS were found areas of $1.74 \pm 0.19 \%$ and $1.62 \pm 0.03 \%$, respectively. Only esters butyl acetate and 2-ethyl hexanoate were not identified in HS-SPME; however, benzyl acetate, ethyl 3-octenoate, hexyl pentanoate, 1-pentyl-2-propenyl butanoate, 4-oxocyclohexyl acetate, and ethyl decanoate ethyl cinnamate were not identified in the S-HSprocedure.

Studies on volatile profile in Passiflora species with extraction procedures in HS-SPME (PDMS/DVB) showed 24 volatile compounds in the yellow passion fruit juice, and the most abundant esters were the methyl hexanoate $(32.9 \%)$, followed by (E)-methyl-2-hexenoate (11.7\%), methyl benzoate (11.3\%), methyl dihydrojasmonate $(6.2 \%)$ (PONTES et al., 2009). However, no volatile methyl esters were found in this study (Table 1).

Terpenes simultaneously identified in both extraction methods were $\beta$-pinene, $\rho$-cimene, limonene, (Z)- $\beta$-ocimene, (E)- $\beta$-ocimene, $\gamma$-terpinene, $\alpha$-terpinolene and (E)-4,8-dimethyl1,3,7-nonatriene. The largest sum of percentages of peak area for terpenes volatile found for the S-HSprocedure with $19.57 \pm 1.19 \%$, while in HSSPME was found $11.94 \pm 0.31 \%$.Although with lower total intensity of peaks, terpenoids recovered in $\mathrm{S}-\mathrm{HS}$ are the same recovered in HS-SPME, showing similarity extraction of terpenes volatile compounds. The similarity in the recovery of terpenes in both extraction techniques shows that these compounds, although not showing the highest concentration, present easily volatile in the fraction of passion fruit juice in comparison with some volatile esters and alcohols, and all aldehydes and ketones which were not identified in the S-HSprocedure. Hexanol, octanol and linalool were the only alcohols extracted and identified simultaneously in S-HS and HS-SPME. Other threealcohols 4-terpineol, (Z)-3,7-dimethyl-2,6-octadien-1-ol and decan-1-ol were identified only in the HS-SPME procedure. In addition to lower extraction efficiency to some esters and alcohols, S-HS procedure was not sensitive to recover volatile ketone and aldehyde groups (Table 1).

\section{CONCLUSION}

This study showed that the S-HS optimized extraction technique was effective to recovery high concentrations of characteristics major volatile compounds in the passion fruit, such as ethyl butanoate and ethyl hexanoate, which can be advantageous due to the simplicity of the method. $\beta$ Pinene, $p$-cymene, limonene, (Z)- $\beta$-ocimene, (E)$\beta$-ocimene, $\gamma$-terpinene, $\alpha$-terpinolene and (E) -4,8-dimethyl-1, 3,7 - nonatriene terpenes were identified with the same similarity of recovery in both techniques. This is important, because together these compounds are considered to be the most important for the characteristic passion fruit flavor.

\section{ACKNOWLEDGMENTS}

The authors acknowledge to the Department of AgriFood Industry, Food and Nutrition/ESALQ/USP for the research infrastructure provided. 


\section{REFERENCES}

ALVAREZ, R. et al. Citrus juice extraction systems: effect on chemical composition andantioxidant activity of clementine juice. Journal of Agricultural and Food Chemistry, v.60, p.774781, 2012. Disponível em: <http://pubs.acs.org/doi/abs/10.1021/ jf203353h>. Acesso em: 15 fev. 2013. Doi 10.1021/jf203353h.

B'HYMER, C. Residual solvent testing: a review of gaschromatographic and alternative techniques. Pharmaceutical research, v.20, p.337-344, 2003. Disponível em: <http:// download.springer.com/static/pdf/283/art\%253A10.1023\%252FA \%253A1022693516409.pdf?auth66=1401546116_48f6ae79912c6 b54547eb7b5c1a43bf2\&ext=.pdf>. Acesso em: 23 mar. 2013. Doi 10.1023/A:1022693516409.

BARBONI, T. et al. Volatile composition of hybrids Citrus juices by headspace solid-phase micro extraction/gas chromatography/mass spectrometry. Food Chemistry, v.116, p.382-390, 2009. Disponível em: <http://dx.doi.org/10.1016/j.foodchem.2009.02.031>. Acesso em: 24 mar. 2013. Doi 10.1016/j.foodchem.2009.02.031.

BICCHI C. et al. Headspace sampling of the volatile fraction of vegetable matrices. Journal of Chromatography A, v.1184, p.220-233, 2008. Disponível em: <http://dx.doi.org/10.1016/j. chroma.2007.06.019>. Acesso em: 24 mar. 2013. Doi 10.1016/j. chroma.2007.06.019.

BRAT, P. et al. Free volatile components of passion fruit puree obtained by flash vacuum-expansion. Journal of Agricultural and Food Chemistry, v.48, p.6210-6214, 2000. Disponível em: $<$ http://pubs.acs.org/doi/abs/10.1021/jf000645i $>$. Acesso em: 24 mar. 2013. Doi 10.1021/jf000645i.

BYLAITE, E.; MEYER, A.S. Characterization of volatile aroma compounds of orange juices by three dynamic and static headspace gas chromatography techniques. European Food Research and Technology, v.222, p.176-184, 2006. Disponível em: <http://link. springer.com/article/10.1007/s00217-005-0141-8>. Acesso em 23 nov. 2012. Doi 10.1007/s00217-005-0141-8.

CARASEK, E.; PAWLISZYN, J. Screening of tropical fruit volatile compounds using solid-phase micro extraction (SPME) fibers and internally cooled SPME fiber. Journal of Agricultural and Food Chemistry, v.54, p.8688-8696, 2006. Disponível em: $<$ http://pubs.acs.org/doi/abs/10.1021/jf0613942>. Acesso em 20 nov. 2012. Doi 10.1021/jf0613942.

DU, X. et al. Evaluation of volatiles from two subtropical strawberry cultivars using GC-olfactometry, GC-MS odor activity values, and sensory analysis. Journal of Agricultural and Food Chemistry, v.59, n.23, p.12569-12577, 2011. Disponível em: $<$ http://pubs.acs.org/doi/abs/10.1021/jf2030924>. Acesso em: 17 out. 2012. Doi 10.1021/jf2030924

FIGOLI, A. et al. Evaluation of pervaporation process of kiwifruit juice by spme-gc/iontrap mass spectrometry. Desalination, v.250, p.1113-1117, 2010. Disponível em: <http://dx.doi.org/10.1016/j. desal.2009.09.120>. Acesso em 20 nov. 2012. Doi 10.1016/j. desal.2009.09.120.

GUTH, H.; GROSCH, W. Identification of potent odourants in static headspace samples of green and black tea powders on the basis of aroma extract dilution analysis (AEDA).

Flavour and Fragrance Journal, v.8, p.173-178, 1993. Disponível em: <http://onlinelibrary.wiley.com/doi/10.1002/ ffj.2730080402/abstract>. Acesso em 17 out. 2012. Doi $10.1002 /$ ffj. 2730080402 .

JORDÁN, M.J. et al. Characterization of the aromatic profile in aqueous essence and fruit juice of yellow passion fruit (Passiflora edulis Sims F. Flavicarpa Degner) by GC-MS and GC/O. Journal of Agricultural and Food Chemistry, v.50, p.1523-1528, 2002. Disponível em: <http://pubs.acs.org/doi/abs/10.1021/jf011077p $>$. Acesso em 12 out. 2012. Doi 10.1021/jf011077p.

MACORIS, M.S. et al. Volatile compounds from organic and conventional passion fruit (Passiflora edulis F. Flavicarpa) pulp. Ciência e Tecnologia de Alimentos, v.31, n.2, p.430435, 2011. Disponível em: <http://dx.doi.org/10.1590/S010120612011000200023>. Acesso em 20 nov. 2012. Doi 10.1590/ S0101-20612011000200023.

MAHATTANATAWEE, K. et al. Comparison of three lychee cultivar odor profiles using gas chromatography-olfactometry and gas chromatography-sulfur detection. Journal of Agricultural and Food Chemistry, v.55, n.5, p.1939-1944, 2007. Disponível em: <http://pubs.acs.org/doi/abs/10.1021/jf062925p >. Acesso em 12 nov. 2012. Doi 10.1021/jf062925p

MESTRES, M. et al. Application of headspace solid-phase microextraction to the determination of sulphur compounds with low volatility in wines. Journal of Chromatography A, v.945, n.1-2, p.211-219, 2002. Disponível em: <http://dx.doi.org/10.1016/ S0021-9673(01)01521-7>. Acesso em 08 fev. 2013. Doi 10.1016/ S0021-9673(01)01521-7.

MILLER, M.E.; STUART, J.D. Comparison of gas-sampled and spme-sampled static headspace for the determination of volatile flavor components. Analytical Chemistry, v.71, p.23-27, 1999. Disponível em: <http://pubs.acs.org/doi/abs/10.1021/ac980576v>. Acesso em 15 out. 2012. Doi 10.1021/ac980576v.

PONTES, M. et al. Headspace solid-phase microextraction-gas chromatography-quadrupole mass spectrometric methodology for the establishment of the volatile composition of Passiflora fruit species. Microchemical Journal, v.93, p.1-11, 2009. Disponível em: $<$ http://dx.doi.org/10.1016/j.microc.2009.03.010>. Acesso em 15 out. 2012. Doi 10.1016/j.microc.2009.03.010.

RODRÍGUEZ-BURRUEZO, A. et al. Comparative analysis of genotypic diversity in the volatile fraction and aromacontributing compounds of Capsicum fruits from the annuumchinense-frutescen complex. Journal of Agricultural and Food Chemistry, v.58, n.7, p.4388-4400, 2010. Disponível em: <http:// pubs.acs.org/doi/abs/10.1021/jf903931t>. Acesso em 16 out. 2012. Doi 10.1021/jf903931t.

SNOW, N.H.; SLACK, G.C. Head-space analysis in modern gas chromatography. Trends in Analytical Chemistry, v.21, p.608617, 2002. Disponível em: <http://dx.doi.org/10.1016/S01659936(02)00802-6>. Acesso em 16 out. 2012. Doi 10.1016/S01659936(02)00802-6

UBEDA, C. et al. Determination of major volatile compounds during the production of fruit vinegars by static headspace gas chromatography-mass spectrometry method. Food Research International, v.44, p.259-268, 2011. Disponível em: $<\mathrm{http}$ :/ dx.doi.org/10.1016/j.foodres.2010.10.025>. Acesso em 16 out. 2012. Doi 10.1016/j.foodres.2010.10.025.

VARMING, C. et al. Comparison of isolation methods for the determination of important aroma compounds in black currant 
(Ribes nigrum L.) juice, using nasal impact frequency profiling. Journal of Agricultural and Food Chemistry, v.52, p.16471652, 2004. Disponível em: < http://pubs.acs.org/doi/abs/10.1021/ jf035133t $>$. Acesso em 15 out. 2012. Doi 10.1021/jf035133t.

WANG, Y. et al. Recent advances in headspace gas chromatography. Journal of Liquid Chromatography and Related Technologies, v.31, p.1823-1851, 2008. Disponível em: <http://www.tandfonline.
com/doi/abs/10.1080/10826070802129092\#.U4eZr3YUN8w>. Acesso em 22 nov. 2012. Doi 10.1080/10826070802129092.

WERKHOFF, P. et al. Vacuum headspace method in aroma research: Flavor chemistry of yellow passion fruits. Journal of Agricultural and Food Chemistry, v.46, p.1076-1093, 1998. Disponível em: <http://pubs.acs.org/doi/abs/10.1021/jf970655s > Acesso em 22 nov. 2012. Doi 10.1021/jf970655s.

Ciência Rural, v.45, n.2, fev, 2015. 